\title{
Correction to: Urine cell cycle arrest biomarkers distinguish poorly between transient and persistent AKI in early septic shock: a prospective, multicenter study
}

Dimitri Titeca-Beauport ${ }^{*}$, Delphine Daubin², Ly Van Vong ${ }^{3}$, Guillaume Belliard ${ }^{4}$, Cédric Bruel ${ }^{5}$, Sami Alaya ${ }^{6}$, Karim Chaoui ${ }^{7}$, Maud Andrieu ${ }^{8}$, Isabelle Rouquette-Vincenti ${ }^{9}$, Frederic Godde ${ }^{10}$, Michel Pascal ${ }^{11}$, Momar Diouf ${ }^{12}$, Christophe Vinsonneau $^{13}$, Kada Klouche ${ }^{2}$ and Julien Maizel ${ }^{1}$

Correction to: Crit Care 24, 280 (2020) https://doi.org/10.1186/s13054-020-02984-6

\section{Correction}

Following publication of the original article [1], the authors reported that Table 2 contained an error. The correct table is given below.

The original article [1] has been updated.

\section{Author details}

'BoReal Study Group, Medical Intensive Care Unit and EA7517, Amiens University Hospital, F-80054 Amiens, France. ${ }^{2}$ Department of Intensive Care Medicine, Lapeyronie University Hospital, Montpellier, France. ${ }^{3}$ Intensive Care Unit, Groupe Hospitalier Sud Ile de France, 270 avenue Marc Jacquet, 77000 Melun, France. ${ }^{4}$ Medical-Surgical Intensive Care Unit, Centre Hospitalier de Bretagne Sud, Lorient, France. ${ }^{5}$ Medical and Surgical Intensive Care Unit, Groupe Hospitalier Paris Saint Joseph, Paris, France. Intensive Care Unit, Centre Hospitalier Général, 13300 Salon-de-Provence, France. ${ }^{7}$ Intensive Care Unit, Jean Rougier Hospital, 335, rue du Président Wilson, 46000 Cahors, France. ${ }^{8}$ Medical and Surgical Intensive Care Unit, Centre Hospitalier de Dax-Côte d'Argent, Dax, France. ${ }^{9}$ Department of Anesthesia and Intensive Care, Princess Grace Hospital, Avenue Pasteur, Monaco (Principality), Monaco.

${ }^{10}$ Département de Réanimation Polyvalente, Centre Hospitalier Avranches-Granville, Granville, France. ${ }^{11}$ Intensive Care Unit, Centre Hospitalier de Mont De Marsan, 40000 Mont-de-Marsan, France. ${ }^{12}$ Clinical Research and Innovation Directorate, Amiens University Hospital, Amiens, France. ${ }^{13}$ BoReal Study Group, Intensive Care Unit, Hôpital de Bethune, 62408 Bethune, France.
Published online: 04 August 2020

\section{Reference}

1. Titeca-Beauport D, Daubin D, Van Vong L, et al. Urine cell cycle arrest biomarkers distinguish poorly between transient and persistent AKI in early septic shock: a prospective, multicenter study. Crit Care. 2020;24:280. https:// doi.org/10.1186/s13054-020-02984-6.

The original article can be found online at https://doi.org/10.1186/s13054020-02984-6.

* Correspondence: titeca.dimitri@chu-amiens.fr

${ }^{1}$ BoReal Study Group, Medical Intensive Care Unit and EA7517, Amiens University Hospital, F-80054 Amiens, France

Full list of author information is available at the end of the article

C The Author(s). 2020 Open Access This article is licensed under a Creative Commons Attribution 4.0 International License, which permits use, sharing, adaptation, distribution and reproduction in any medium or format, as long as you give appropriate credit to the original author(s) and the source, provide a link to the Creative Commons licence, and indicate if changes were made. The images or other third party material in this article are included in the article's Creative Commons licence, unless indicated otherwise in a credit line to the material. If material is not included in the article's Creative Commons licence and your intended use is not permitted by statutory regulation or exceeds the permitted use, you will need to obtain permission directly from the copyright holder. To view a copy of this licence, visit http://creativecommons.org/licenses/by/4.0/ The Creative Commons Public Domain Dedication waiver (http://creativecommons.org/publicdomain/zero/1.0/) applies to the data made available in this article, unless otherwise stated in a credit line to the data. 
Table 2 Variation of [TIMP-2]*[IGFBP7] at different time points

\begin{tabular}{|c|c|c|c|c|c|}
\hline Parameters & Sample $(n)$ & Total cohort & Transient AKI & Persistent AKI & $p$-value \\
\hline 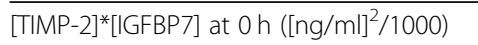 & 184 & $1.26[0.26-4.00]$ & $0.75[0.20-2.12]$ & $2.21[0.81-4.90]$ & $<0.001$ \\
\hline [TIMP-2]*[IGFBP7] at $6 \mathrm{~h}\left([\mathrm{ng} / \mathrm{ml}]^{2} / 1000\right)$ & 172 & $0.71[0.22-2.86]$ & $0.37[0.13-1.38]$ & $2.02[0.54-5.43]$ & $<0.001$ \\
\hline [TIMP-2]*[IGFBP7] at $12 \mathrm{~h}\left([\mathrm{ng} / \mathrm{ml}]^{2} / 1000\right)$ & 165 & $0.50[0.19-1.59]$ & $0.33[0.13-0.78]$ & $1.19[0.30-3.8]$ & $<0.001$ \\
\hline [TIMP-2]*[IGFBP7] at $24 \mathrm{~h}\left([\mathrm{ng} / \mathrm{ml}]^{2} / 1000\right)$ & 156 & $0.46[0.16-1.18]$ & $0.32[0.12-0.86]$ & $0.69[0.26-2.36]$ & $<0.001$ \\
\hline$\Delta[\text { [IMP-2] }]^{*}[$ IGFBP7] $0 \mathrm{~h}$ to $6 \mathrm{~h}(\%)$ & 172 & $-20.0[-76.4-74.7]$ & $11.3[-48.6-111.1]$ & $-36.5[-79.4-49.7]$ & 0.04 \\
\hline$\Delta[$ TIMP-2]*[IGFBP7] $0 \mathrm{~h}$ to $12 \mathrm{~h}(\%)$ & 165 & $-39.1[-77.2-56.4]$ & $-19.0[-70.6-100.4]$ & $-50.0[-84.0-50.0]$ & 0.13 \\
\hline$\Delta[$ TIMP-2]*[IGFBP7] $12 \mathrm{~h}$ to $24 \mathrm{~h}(\%)$ & 156 & $0.0[-77.3-56.4]$ & $3.7[-76.0-48.7]$ & $0.0[-66.7-51.5]$ & 0.99 \\
\hline
\end{tabular}

Median and interquartile range 